\title{
Measurement Natural Radioactivity in Soil Samples from Important historical locals in Alnajaf Alashraf city, Iraq. \\ ${ }^{1}$ Heiyam N. Majeed, ${ }^{2}$ Ali K. Hasan, ${ }^{3}$ Hussein J. Hamad \\ ${ }^{1} 2^{\prime} 3$ Education College of girls, Kufa University, Al-Najaf Al-Ashraf, Kufa, Iraq. \\ heiyam_najy@yahoo.com \\ alikh_hasan@yahoo.com
}

\section{ABSTRACT}

Al-Najaf Al-Ashraf city one of the most important ,oldest, historical and religious cities in Iraqi country which includes hundreds of holy shrines and historical mosques which over the built hundreds of years. The natural radiation of forty two samples of soil which collected randomly in June 2013 from different religious and historical places were measured using $3 " \times 3 " \mathrm{Na}(\mathrm{TI})$ detection. The mean values activity concentrations of $238 \mathrm{U}, 232 \mathrm{Th}$ and $40 \mathrm{~K}$ was $(23.59 \pm 4.37,12.10 \pm 0.54$ and 60.68 \pm 2.30$) \mathrm{Bq} \mathrm{kg}-1$ respectively, specific activity for all soil sample were in the worldwide average. The average values of the Radium equivalent activity and annual effective dose were $(22.455 \mathrm{~Bq} / \mathrm{kg}$ and $25.375 \mu \mathrm{Sv} / \mathrm{y})$ less than the world average. The heist external and internal hazard and gamma activity concentration index were $(0.274,0.412$ and $0.705)$ lower than unity.

\section{Keywords}

Gamma ray spectrometry; $\mathrm{Na}(\mathrm{TI})$ detector; Raeq activities and annual effective dose.

\section{Council for Innovative Research}

Peer Review Research Publishing System

\section{Journal: Journal of Advances in Chemistry}

Vol. 8, No. 1

editor@cirworld.com

www.cirjac.com, member.cirworld.com 


\section{INTRODUCTION}

Al Najaf city have been Enjoyed in religious and cultural prestigious, they are a natural extension of Kufa capital of the Islamic caliphate days of Imam Ali bin Abi Talib (peace be upon him), in al Najaf city many shrines and most important mosque.

Shrine of Imam Ali -also known as Alhaidariya holy - in the center of Najaf it refers as the advantage Islamic architectural style construction, and is considered one of the most important mosques and religious shrines in Iraq because it includes the remains of the Imam Ali bin Abi Talib who was martyred in 40 AH (661 AD).

Shrine of the Prophets Hood and Saleh is located in the Najaf cemetery major behind the city wall the old hand and the Valley of Peace shrine of prophets Hood and Saleh on the campus of one meant visitor to prayer and blessing, also Camille ibn Ziyad Nakha'I Shrine who realized the life of the Messenger of Allah 18 years old, and Imam Ali as well as the shrine of Muslim Ibn Aqil "al Hussein ambassador" and al Sahaabi Maitham al Tamar shrine and the house of Imam Ali which known as Bait Fatima and al sahlaa mosque and many other religious and historical places.

In this research the natural radioactivity level of elected soils of these shrines, religious places and historical holy has been studied because of religious and historical importance in addition to the large number of visitors It is important to identify the concentration of radioactive isotopes in soil because it constitutes a path for radioactivity to humans and is an indicator of radioactive accumulation in the environment $[1,2]$.

Natural sources of radiation are cosmic radiation and terrestrial radiation arising from the decay of naturally occurring radioactive substance, if the half life of a radionuclide found in geological strata approximates the estimated age of the earth ,then the radionuclide is primordial .it was presumably present from the time of the earth's beginning .Inventories of primordial radionuclide $s$ are essential parts of the natural background level of radioactivity in the environment .the concentrations of the natural radio nuclides ${ }^{238} \mathrm{U},{ }^{232} \mathrm{Th}$, their daughter products and ${ }^{40} \mathrm{~K}$, present in the soil and rocks which in turn depend upon the local geology of each reigion in the world are causes of variation of doses. Some areas are high natural background areas because in these areas levels of uranium and its decay products in rock and soil ,high background radiation areas are due to local geology, location altitude and geochemical effects that cause enhanced levels of terrestrial radiation[3-9].

\section{EXPERIMENTAL PROCEDURES :}

The soil samples measured at $(0-5) \mathrm{cm}$ depth level were collected from sampling points located at religious and historical places. The location of the samples is shown on table (1) and figure (1) after collection,samples are crushed into fine powder by grinder ,fine quality of the sample is obtained using scientific sieve .before measurement samples are dried in an oven at a temperature of $60 \mathrm{C}-$ for $72 \mathrm{~h}$, each sample is packed and sealed in an airtight PVC container and kept for about (4) weeks period to allow radioactive equilibrium among the daughter products of radon $\left({ }^{222} \mathrm{Rn}\right)$, thoron $\left({ }^{220} \mathrm{Rn}\right)$ and their short lived decay products . an average (1) $\mathrm{kg}$ of soil is used per sample.

To measured the specific activity we used $\mathrm{Nal}(\mathrm{TI})$ a system which consist of a scintillation detector $\mathrm{Nal}(\mathrm{TI})$ of $(3 " \times 3 ")$ crystal dimension, supplied by (Alpha Spectra,Inc), coupled with a multi-channel analyzer (MCA) (ORTEC -Digi Base) with range of 4096 channel joined with ADC (Analog to Digital Convertor) unit, through interface. The spectral data was converted directly to the PC of the laboratory introduced by using (MAESTRO-32) software. The detector was enclosed in a graded lead shield. The gamma spectra of the collected samples were measured and the activities of $238 \mathrm{U}$ series,232Th series and $40 \mathrm{~K}$ in each sample were determined by measuring the characteristic gamma-peaks of their daughters. The line at $1764 \mathrm{keV}$ of ${ }^{214} \mathrm{Bi}$ was used to determine ${ }^{238} \mathrm{U}$ series activity, and the line at $2614 \mathrm{keV}$ of ${ }^{208} \mathrm{TI}$ for ${ }^{232}$ Th series. Also the peak at $1460 \mathrm{keV}$ was used for ${ }^{40} \mathrm{~K}$ activity $[10,11]$

The specific activity of each radionuclide is calculated using the following equation

$$
A=\frac{N_{n e t}}{\varepsilon \cdot I_{\gamma} \cdot m \cdot t} \pm \frac{\sqrt{N_{n e t}}}{\varepsilon \cdot I_{\gamma} \cdot m \cdot t}\left[B q \cdot \mathrm{kg}^{-1}\right]
$$

Where $N_{n e t}$ is the net count (area under the specified energy peak after back ground subtraction ) in (c/s), $\sqrt{N_{\text {net }}}$ is the random error in $(\mathrm{c} / \mathrm{s}), \varepsilon$ is the efficiency of the detector, Iy is the transition probability of the emitted gamma ray ,t is the time (in sec)for spectrum collected and $\mathrm{m}$ is the sample weight (in $\mathrm{kg}$ ).

\section{Radium equivalent activity $\left(\mathbf{R} \mathbf{a}_{\mathrm{eq}}\right)$ :}

Distribution of ${ }^{238} \mathrm{U},{ }^{232} \mathrm{Th}$ and ${ }^{40} \mathrm{~K}$ in environment is not uniform, so that with respect to exposure to radiation, the radioactivity has been defined in terms of radium equivalent activity (Raeq) in Bq.kg-1 [12-14].

$$
R a_{e q}=A_{U}+1.43 A_{T h}+0.077 A_{K}
$$

Where $A_{U}, A_{T h}$ and $A_{K}$ are specific activity concentration in Bq.kg-1 of ${ }^{238} U{ }^{232} \mathrm{Th}$ and ${ }^{40} \mathrm{~K}$, respectively. The index is useful to compare the specific activity of materials containing different concentrations of ${ }^{238} \mathrm{U}{ }^{232} \mathrm{Th}$ and ${ }^{40} \mathrm{~K}$. 


\section{Gamma Dose Rate (D)}

The total dose rate $\mathrm{D}$ in the air (out doors) due to uniform distribution of all the ${ }^{226} \mathrm{Ra},{ }^{232} \mathrm{Th}$ and ${ }^{40} \mathrm{~K}$ in the beach soil 1 $\mathrm{m}$ above the ground surface was estimated by [12-14]:

$$
D=0.427 A_{U}+0.662 A_{T h}+0.043 A_{K} \ldots . .(3)
$$

Where $D$ is the dose rate in $\left(n G y \cdot h^{-1}\right)$ and $A_{U}, A_{T h}$ and $A_{K}$ are the concentrations of uranium, thorium and potassium, respectively.

\section{Annual Effective Dose Equivalent (AEDE)}

In order to estimate the annual effective dose rate in air the conversion coefficient from absorbed dose in air to effective dose received by an adult had to be taken into consideration .This value is published in UNSCEAR (2000)[5] of( 0.7 Sv/Gy). The outdoor occupancy factor which is about (0.2) .

The annual effective dose equivalent was given by the following equation[12-16] :

$$
\operatorname{AEDE}(\mu \mathrm{Sv} / \mathrm{y})=\mathrm{D}(\mathrm{nGy} / \mathrm{h}) \times 8760(\mathrm{~h} / \mathrm{y}) \times 0.2 \times 0.7(\mathrm{~Sv} / \mathrm{Gy}) \times 10^{-3}
$$

\section{Representative level index (lyr)}

In order to examine whether the sample meets limits of dose criteria ,Another radiation hazard index, representative level index lyr, used to estimate the level of $y$ - radiation hazard associated with the radionuclides in specific investigated samples ,is defind as the following equation [12-15]:

$$
I_{r}=A_{U} / 300+A_{T h} / 200+A_{K} / 3000 \ldots . .(5)
$$

The index lyr was correlated with the annual dose due to the excess external gamma radiation caused by superficial material. Values of index I $\leq 1$ correspond to $0.3 \mathrm{mSv} / \mathrm{y}$, while I $\leq 3$ correspond to $1 \mathrm{mSv} / \mathrm{y}$. Thus, the activity concentration index should be used only as a screening tool for identifying materials which might be of concern to be used as covering material. According to this dose criterion, materials with $\mathrm{I} \leq 3$ should be avoided[15].

\section{External hazard index $\left(\mathrm{H}_{\mathrm{ex}}\right)$}

The external hazard index $\left(\mathrm{H}_{\mathrm{ex}}\right)$ was given by the following equation[12-15]

$$
H_{e x}=\frac{A_{R a}}{370}+\frac{A_{T h}}{259}+\frac{A_{K}}{4810} \ldots \ldots
$$

\section{Internal hazard index $\left(\mathrm{H}_{\text {in }}\right)$}

The internal exposure to ${ }^{222} \mathrm{Rn}$ and its radioactive progeny is controlled by the internal hazard index $\left(\mathrm{H}_{\text {in }}\right)$ is given by $[13,14]$

$$
H_{\text {in }}=\frac{A_{R a}}{185}+\frac{A_{T h}}{259}+\frac{A_{K}}{4810} \ldots . .(7)
$$

For the safe use of a material in the construction of dwellings, index $\left(\mathrm{H}_{\text {in }}\right)$ should be less than unity and the maximum value of $\left(\mathrm{H}_{\text {in }}\right)$ to be less than unity.

\section{RESULTS AND DISCUSSIONS:}

The specific activity values of ${ }^{238} \mathrm{U},{ }^{232} \mathrm{Th}$ and ${ }^{40} \mathrm{~K}$ radionuclide $\mathrm{s}$ for 42 soil sample are tabulated in table (1). They have been found to lie in the range of $(5.89 \pm 2.23 ; \mathrm{S} 3$ to $36.20 \pm 5.52 ; \mathrm{S} 29) \mathrm{Bq} / \mathrm{kg}$ with an average of $23.59 \pm 4.37 \mathrm{~Bq} / \mathrm{kg}$, from $(0.72 \pm 0.16 ; \mathrm{S} 28$ to $31.68 \pm 1.04 ; \mathrm{S} 16) \mathrm{Bq} / \mathrm{kg}$ with an average $12.10 \pm 0.54 \mathrm{~Bq} / \mathrm{kg}$ and $(20.89 \pm 1.38 ; \mathrm{S} 6$ to $90.63 \pm 2.87 ; \mathrm{S} 18)$ $\mathrm{Bg} / \mathrm{kg}$ with an average $60.68 \pm 2.30 \mathrm{~Bq} / \mathrm{kg}$ for ${ }^{238} \mathrm{U},{ }^{232} \mathrm{Th}$ and ${ }^{40} \mathrm{~K}$ respectively. The result shows that all values of ${ }^{238} \mathrm{U}$ ${ }^{232} \mathrm{Th}$ and ${ }^{40} \mathrm{~K}$ specific activity for all soil sample are in the worldwide average $\left(35 \mathrm{~Bq} / \mathrm{kg}\right.$ for ${ }^{238} \mathrm{U}, 30 \mathrm{~Bq} / \mathrm{kg}$ for ${ }^{232} \mathrm{Th}$ and $400 \mathrm{~Bq} / \mathrm{kg}$ for $\left.{ }^{40} \mathrm{~K}\right)[17,18]$. 
Table (1): Concentrations of radionuclide for each sample in (Bq. $\left.\mathrm{kg}^{-1}\right)$.

\begin{tabular}{|c|c|c|c|c|}
\hline Sample No. & Samples Name & $A^{238} U$ & $A^{232} T h$ & $\mathrm{~A}^{40} \mathrm{~K}$ \\
\hline S1 & the Imam Ali holy shrine (1) & $11.82 \pm 2.5205$ & $14.74 \pm 0.5661$ & $41.73 \pm 1.5554$ \\
\hline S2 & the Imam Ali holy shrine (2) & $25.23 \pm 3.8935$ & $11.06 \pm 0.5185$ & $61.83 \pm 2.0017$ \\
\hline S3 & the Imam Ali holy shrine (3) & $5.89 \pm 2.2274$ & $19.31 \pm 0.8110$ & $74.74 \pm 2.6052$ \\
\hline S4 & the Imam Ali holy shrine (4) & $26.94 \pm 4.7623$ & $16.66 \pm 0.7532$ & $41.41 \pm 1.9392$ \\
\hline S5 & Maqam Hood and Saleh & $21.89 \pm 4.2927$ & $2.15 \pm 0.2703$ & $82.55 \pm 2.7379$ \\
\hline S6 & Maqam Imam al hoja & $27.78 \pm 4.8362$ & $26.87 \pm 0.9567$ & $20.89 \pm 1.3772$ \\
\hline S7 & Beer alawee Mosque & $19.36 \pm 4.0375$ & $8.69 \pm 0.5439$ & $79.01 \pm 2.6786$ \\
\hline S8 & Maqam Ibrahim al gamr & $35.36 \pm 5.4559$ & $23.43 \pm 0.8934$ & $22.70 \pm 1.4359$ \\
\hline S9 & Fatima shrine (1) & $17.68 \pm 3.8579$ & $29.50 \pm 1.0023$ & $30.88 \pm 1.6745$ \\
\hline S10 & Fatima shrine (2) & $19.36 \pm 4.0375$ & $20.03 \pm 0.8259$ & $60.84 \pm 2.3506$ \\
\hline S11 & Fatima shrine (3) & $21.89 \pm 4.2927$ & $22.27 \pm 0.8710$ & $88.09 \pm 2.8283$ \\
\hline S12 & Fatima shrine (4) & $17.68 \pm 3.8579$ & $26.57 \pm 0.9512$ & $80.82 \pm 2.7092$ \\
\hline S13 & Safee alsafa shrine (1) & $12.63 \pm 3.2605$ & $22.14 \pm 0.8683$ & $72.65 \pm 2.5685$ \\
\hline S14 & Safee alsafa shrine (2) & $26.94 \pm 4.7623$ & $7.83 \pm 0.5165$ & $48.13 \pm 2.0906$ \\
\hline S15 & Safee alsafa shrine (3) & $24.41 \pm 4.5336$ & $25.75 \pm 0.9365$ & $57.21 \pm 2.2794$ \\
\hline S16 & Maqam roqea bint al Hassan & $16.84 \pm 3.7650$ & $31.68 \pm 1.0387$ & $22.70 \pm 1.4359$ \\
\hline S17 & Camille ibn Ziyad shrine (1) & $15.15 \pm 3.5718$ & $22.99 \pm 0.8849$ & $42.68 \pm 1.9688$ \\
\hline S18 & Camille ibn Ziyad shrine (2) & $30.31 \pm 5.0512$ & $30.52 \pm 1.0195$ & $90.63 \pm 2.8688$ \\
\hline S19 & Camille ibn Ziyad shrine (3) & $17.68 \pm 3.8579$ & $22.24 \pm 0.8704$ & $68.56 \pm 2.4953$ \\
\hline S20 & $\begin{array}{l}\text { Hussienieh Al rasol ala'adm - } \\
\text { Mashkhab }\end{array}$ & $21.05 \pm 4.2094$ & $23.47 \pm 0.8940$ & $38.32 \pm 1.8655$ \\
\hline S21 & Hussienieh Mashkhab-Mashkhab & $16.00 \pm 3.6696$ & $30.31 \pm 1.0161$ & $65.57 \pm 2.4401$ \\
\hline S22 & $\begin{array}{l}\text { mosque Al rasol ala'adm- } \\
\text { Mashkhab }\end{array}$ & $15.15 \pm 3.5718$ & $15.33 \pm 0.7225$ & $77.19 \pm 2.6476$ \\
\hline S23 & Sons of Imam Kadhim shrine & $30.31 \pm 5.0512$ & $11.38 \pm 0.6225$ & $86.82 \pm 2.8078$ \\
\hline S24 & Nabi Younis shrine & $15.15 \pm 3.5718$ & $22.14 \pm 0.8683$ & $69.02 \pm 2.5035$ \\
\hline S25 & Maitham al Tamar shrine & $27.78 \pm 4.8362$ & $0.78 \pm 0.1633$ & $59.84 \pm 2.3312$ \\
\hline S26 & Faithful home (1) & $31.15 \pm 5.1209$ & $1.09 \pm 0.1927$ & $41.59 \pm 1.9435$ \\
\hline S27 & Faithful home (2) & $28.62 \pm 4.9089$ & $1.46 \pm 0.2233$ & $69.47 \pm 2.5117$ \\
\hline S28 & Faithful home (3) & $20.20 \pm 4.1243$ & $0.72 \pm 0.1561$ & $89.27 \pm 2.8472$ \\
\hline S29 & Faithful home (4) & $36.20 \pm 5.5205$ & $1.02 \pm 0.1866$ & $86.00 \pm 2.7946$ \\
\hline S30 & Alsahlaa mosque (1) & $31.15 \pm 5.1209$ & $1.12 \pm 0.1957$ & $54.31 \pm 2.2207$ \\
\hline S31 & Alsahlaa mosque (2) & $31.99 \pm 5.1896$ & $0.75 \pm 0.1598$ & $54.31 \pm 2.2207$ \\
\hline S32 & Alsahlaa mosque (3) & $19.36 \pm 4.0375$ & $0.78 \pm 0.1633$ & $59.39 \pm 2.3224$ \\
\hline S33 & Alsahlaa mosque (4) & $22.73 \pm 4.3745$ & $0.82 \pm 0.1669$ & $54.49 \pm 2.2244$ \\
\hline S34 & Muslim Ibn Aqil shrine (1) & $28.62 \pm 4.9089$ & $0.89 \pm 0.1737$ & $63.48 \pm 2.4$ \\
\hline S35 & Muslim Ibn Aqil shrine (2) & $29.47 \pm 4.9806$ & $1.46 \pm 0.2233$ & $84.73 \pm 2.7738$ \\
\hline
\end{tabular}




\begin{tabular}{|c|l|c|c|c|}
\hline S36 & Muslim Ibn Aqil shrine (3) & $27.78 \pm 4.8362$ & $1.23 \pm 0.2044$ & $51.49 \pm 2.1624$ \\
\hline S37 & Muslim Ibn Aqil shrine (4) & $33.67 \pm 5.3245$ & $1.57 \pm 0.2310$ & $52.40 \pm 2.1814$ \\
\hline S38 & Aolad al Hassan shrine -Manathira & $28.62 \pm 4.9089$ & $1.53 \pm 0.2285$ & $77.64 \pm 2.6554$ \\
\hline S39 & Kufa mosque (1) & $21.05 \pm 4.2094$ & $1.50 \pm 0.2259$ & $61.48 \pm 2.3629$ \\
\hline S40 & Kufa mosque (2) & $31.15 \pm 5.1209$ & $1.16 \pm 0.1986$ & $40.41 \pm 1.9157$ \\
\hline S41 & Kufa mosque (3) & $16.84 \pm 3.7650$ & $1.23 \pm 0.2044$ & $60.21 \pm 2.3383$ \\
\hline S42 & Kufa mosque (4) & $31.99 \pm 5.1896$ & $1.87 \pm 0.2526$ & $63.11 \pm 2.3941$ \\
\hline Average & & $23.59 \pm 4.37$ & $12.10 \pm 0.54$ & $60.68 \pm 2.30$ \\
\hline Max. & & $36.20 \pm 5.52$ & $31.68 \pm 1.04$ & $90.63 \pm 2.87$ \\
\hline Min. & & $5.89 \pm 2.23$ & $0.72 \pm 0.16$ & $20.89 \pm 1.38$ \\
\hline
\end{tabular}

The radium equivalent activities was calculated and listed in table (2) .Ra eq values vary from (5.143;S40 to 50.872;S18 ) $\mathrm{Bq} / \mathrm{kg}$ with average value of $(22.455) \mathrm{Bq} / \mathrm{kg}$.It can seen be that the $\mathrm{Ra}$ eq values for all samples are lower than the recommended value $370 \mathrm{~Bq} / \mathrm{kg}[17,18]$.Gamma Dose Rate (D),Annual Effective Dose Equivalent (AEDE), Representative level index (lyr) ,External hazard index $\left(\mathrm{H}_{\mathrm{ex}}\right)$ and Internal hazard index $\left(\mathrm{H}_{\mathrm{in}}\right)$ are calculated and listed in table (2) the Gamma Dose Rate (D) range from (10.590;S41 to 37.041;S18) nGy/h with average $20.691 \mathrm{nGy} / \mathrm{h}$, the (AEDE) rang are from (12.988;S41 to $45.427 ; \mathrm{S} 18)(\mu \mathrm{Sv} / \mathrm{y})$ with average $25.375(\mu \mathrm{Sv} / \mathrm{y})$ all the soil samples have the annual effective dose less than the world average 460 ( $\mu \mathrm{Sv} / \mathrm{y})$ [17,18], Representative level index (Iyr) range from $(0.073 ; S 40$ to $0.705 ; S 18)$ with average 0.311, External hazard index $\left(\mathrm{H}_{\mathrm{ex}}\right)$ range from $(0.027 ; \mathrm{S} 40$ to $0.274 ; \mathrm{S} 18)$ with average 0.120 and Internal hazard index $\left(\mathrm{H}_{\text {in }}\right)$ range from $(0.041 ; \mathrm{S} 40$ to $0.412 ; \mathrm{S} 18)$ with average 0.181 . External and internal hazard and gamma activity concentration were lower than unity according to the Radiation Protection 112 [17].

Table (2): Radium equivalent (Bq.kg $\left.{ }^{-1}\right)$, Dose rate (nGy/h), AEDE ( $\left.\mu \mathrm{Sv} / \mathrm{y}\right)$, the internal and external hazard indexes representative level index for all samples.

\begin{tabular}{|c|c|c|c|c|c|c|}
\hline $\begin{array}{c}\text { Sample } \\
\text { No. }\end{array}$ & $\mathrm{Ra}$ eq & $\mathrm{D}(\mathrm{nGy} / \mathrm{h})$ & $\mathrm{AEDE}(\mu \mathrm{Sv} / \mathrm{y})$ & $\mathrm{H}_{\text {in }} \leq 1$ & $\mathrm{H}_{\mathrm{ex}} \leq 1$ & $\mathrm{I}_{\mathrm{rr}} \leq 1$ \\
\hline $\mathrm{S} 1$ & 24.654 & 16.600 & 20.359 & 0.199 & 0.132 & 0.340 \\
\hline $\mathrm{S} 2$ & 20.915 & 20.754 & 25.453 & 0.169 & 0.112 & 0.291 \\
\hline $\mathrm{S} 3$ & 33.969 & 18.514 & 22.706 & 0.274 & 0.182 & 0.469 \\
\hline $\mathrm{S} 4$ & 27.614 & 24.310 & 29.813 & 0.222 & 0.148 & 0.378 \\
\hline $\mathrm{S} 5$ & 9.759 & 14.316 & 17.558 & 0.078 & 0.052 & 0.142 \\
\hline $\mathrm{S} 6$ & 40.665 & 30.551 & 37.467 & 0.328 & 0.218 & 0.554 \\
\hline $\mathrm{S} 7$ & 18.858 & 17.415 & 21.358 & 0.152 & 0.101 & 0.265 \\
\hline $\mathrm{S} 8$ & 35.551 & 31.587 & 38.738 & 0.287 & 0.191 & 0.486 \\
\hline $\mathrm{S} 9$ & 44.769 & 28.403 & 34.833 & 0.362 & 0.241 & 0.614 \\
\hline $\mathrm{S} 10$ & 34.114 & 24.142 & 29.608 & 0.274 & 0.182 & 0.468 \\
\hline $\mathrm{S} 11$ & 39.427 & 27.880 & 34.192 & 0.317 & 0.211 & 0.544 \\
\hline $\mathrm{S} 12$ & 44.781 & 28.611 & 35.089 & 0.361 & 0.240 & 0.618 \\
\hline $\mathrm{S} 13$ & 37.415 & 23.172 & 28.418 & 0.303 & 0.202 & 0.519 \\
\hline S14 & 15.699 & 18.759 & 23.006 & 0.125 & 0.083 & 0.215 \\
\hline $\mathrm{S} 15$ & 42.007 & 29.931 & 36.707 & 0.338 & 0.225 & 0.576 \\
\hline $\mathrm{S} 16$ & 47.581 & 29.135 & 35.731 & 0.384 & 0.256 & 0.649 \\
\hline S17 & 36.385 & 23.525 & 28.852 & 0.294 & 0.196 & 0.501 \\
\hline S18 & 50.872 & 37.041 & 45.427 & 0.412 & 0.274 & 0.705 \\
\hline & & & & & & \\
\hline
\end{tabular}




\begin{tabular}{|c|c|c|c|c|c|c|}
\hline S19 & 37.287 & 25.221 & 30.931 & 0.302 & 0.201 & 0.517 \\
\hline S20 & 37.076 & 26.170 & 32.095 & 0.299 & 0.199 & 0.507 \\
\hline S21 & 48.710 & 29.717 & 36.444 & 0.394 & 0.262 & 0.672 \\
\hline S22 & 28.358 & 19.936 & 24.450 & 0.229 & 0.152 & 0.394 \\
\hline S23 & 23.561 & 24.205 & 29.685 & 0.189 & 0.126 & 0.329 \\
\hline S24 & 37.480 & 24.094 & 29.549 & 0.302 & 0.201 & 0.517 \\
\hline S25 & 6.316 & 14.955 & 18.340 & 0.050 & 0.033 & 0.090 \\
\hline S26 & 5.339 & 15.811 & 19.390 & 0.042 & 0.027 & 0.074 \\
\hline S27 & 7.920 & 16.179 & 19.842 & 0.063 & 0.042 & 0.114 \\
\hline S28 & 8.343 & 12.940 & 15.869 & 0.066 & 0.044 & 0.122 \\
\hline S29 & 8.762 & 19.832 & 24.322 & 0.069 & 0.046 & 0.126 \\
\hline S30 & 6.164 & 16.380 & 20.088 & 0.049 & 0.032 & 0.089 \\
\hline S31 & 5.638 & 16.491 & 20.225 & 0.045 & 0.029 & 0.081 \\
\hline S32 & 6.190 & 11.340 & 13.908 & 0.049 & 0.032 & 0.089 \\
\hline S33 & 5.871 & 12.590 & 15.440 & 0.046 & 0.030 & 0.084 \\
\hline S34 & 6.722 & 15.538 & 19.056 & 0.053 & 0.035 & 0.096 \\
\hline S35 & 9.176 & 17.195 & 21.087 & 0.073 & 0.048 & 0.132 \\
\hline S36 & 6.387 & 14.889 & 18.259 & 0.050 & 0.033 & 0.089 \\
\hline S37 & 6.975 & 17.669 & 21.670 & 0.055 & 0.036 & 0.097 \\
\hline S38 & 8.515 & 16.576 & 20.328 & 0.068 & 0.045 & 0.124 \\
\hline S39 & 7.130 & 12.623 & 15.480 & 0.057 & 0.038 & 0.104 \\
\hline S40 & 5.143 & 15.805 & 19.383 & 0.041 & 0.027 & 0.073 \\
\hline S41 & 6.866 & 10.590 & 12.988 & 0.054 & 0.036 & 0.098 \\
\hline S42 & 8.127 & 17.614 & 21.602 & 0.064 & 0.042 & 0.115 \\
\hline Average & 22.455 & 20.691 & 25.375 & 0.181 & 0.120 & 0.311 \\
\hline Max. & 50.872 & 37.041 & 45.427 & 0.412 & 0.274 & 0.705 \\
\hline Min. & 5.143 & 10.590 & 12.988 & 0.041 & 0.027 & 0.073 \\
\hline & & & & & & \\
\hline S3 & & & & & \\
\hline
\end{tabular}

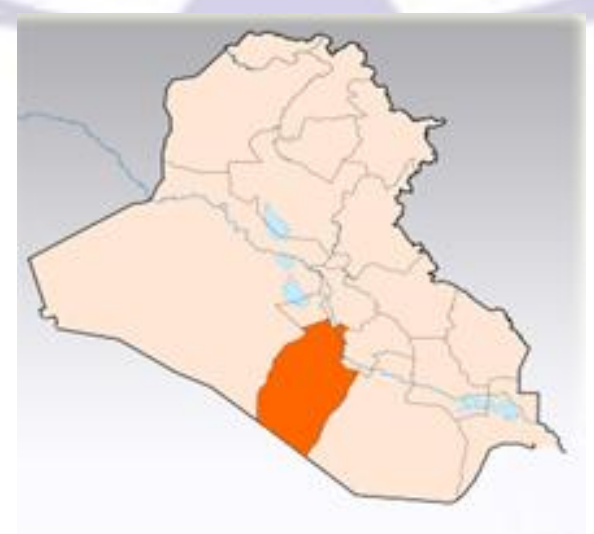

Figure 1: Map of Al-Najaf city 


\section{CONCLUSIONS:}

The activity concentrations of ${ }^{238} \mathrm{U},{ }^{232} \mathrm{Th}$ and ${ }^{40} \mathrm{~K}$ for (42) soil sample from differences religious and historical places was determined. The activity concentrations were measured using $\mathrm{Na}(\mathrm{TI})$ detection. The mean values activity concentrations of ${ }^{238} \mathrm{U},{ }^{232} \mathrm{Th}$ and ${ }^{40} \mathrm{~K}$ was $(23.59 \pm 4.37,12.10 \pm 0.54$ and60.68 \pm 2.30$) \mathrm{Bq} \mathrm{kg}^{-1}$ respectively. The values of the Radium equivalent activity and annual effective dose was less than the world average .External and internal hazard and gamma activity concentration (representative level index) indexes were lower than unity.

\section{REFERENCES:}

[1] R. Kathren “ radioactivity in the environment sources distribution and surveillance” ,Harwood academic publishers ,New York,(1984).

[2] G. Choppin , R. Rydberg and J. Liljenzin "radiochemistry and nuclear chemistry " $2^{\text {nd }}$ edition of nuclear chemistry theory and applications , New York , Pergmon Press , (1995)

[3] L. Quindos, P. Fernandez, C. Rodenas, J. Gomez-Arozamena and J. Arteche, "Conversion factors for external gamma dose derived from natural radionuclides in soils", Journal of Environmental Radioactivity, 71, 139- 145 (2004).

[4] H. Ibrahim , A. Hafez, N. Elanany, H. Motaweh and M. Naim; "Radiological Study on Soils, Foodstuff and Fertilizers in the Alexandria Region, Egypt”, Turkish J. Eng. Env. Sci. 30, 1-9 (2006).

[5] United Nations Scientific Committee on the Effects of Atomic Radiation , Sources, Effects and Risks of lonizing Radiation ,New York ,United Nations, 2000.

[6]V. Ramasamy, G.Suresh, V.Meenakshisundaram and V.Gajendran," Evaluation of Natural Radionuclide Content in River Sediments and Excess Lifetime Cancer Risk Due to Gamma Radioactivity", Research Journal of Environmenal and Earth Sciences 1: 6-10, (2009).

[7] A. Msitah ,H. Zaini ,S.Ahmad, O. Mohamat and W. Abdul Khalik ,"An assessment of absorbed dose and radiation hazard index from natural radioactivity " Journal of the Malaysian Journal of Analytical sciences 12:195-204(2008).

[8] Naturally Occurring Radioactive Material (NORM V) Proceedings of an international symposium Seville, Spain, 19-22 March 2007

[9] L. Colmenero Sujo , M. Montero Cabrera , L. Villalba , M. Renteri'a Villalobos , E. Torres Moye , M. Garc Leon ,R. Garc -Tenorio ,. Mireles Garcl, E. Herrera Peraza and D. Sanchez Aroche " Uranium-238 and thorium-232 series concentrations in soil, radon-222 indoor and drinking water concentrations and dose assessment in the city of Aldama, Chihuahua, Mexico', Journal of Environmental Radioactivity 77 ,205-219,(2004).

[10] IAEA , International atomic energy agency, Update of $x$ ray and gamma ray decay data standards for detector calibration and other applications, Volume 1 ,Vienna ,2007

[11] IAEA, International atomic energy agency, "Guidelines for radioelement mapping using gamma ray spectrometry data", Vienna, (2003).

[12] H .Al-Sulaiti, P .Regan, D .Bradley, M .Matthews, T. Santawamaitre and D .Malain, "Preliminary Determination of Natural Radioactivity Levels of the State of Qatar using High Resolution Gamma ray spectrometry",IX Radiation. Physics \& Protection Conference, 15-19 November Nasr City - Cairo, Egypt (2008) .

[13] S. Radenković,V.Alshikh,V. Andric ,and S. Miljanic, J. Serb. Chem. Soc. 74 :461-470, (2009).

[14] S .Harb, A.El-Kamel, A.Abd El-Mageed and R.Wafaa,Proceedings of the 3 rd Environmental Physics Conference , 19 23 Feb. Aswan, Egypt (2008).

[15] F.Al - Saleh and B .Al-Berzan ,Journal of Nuclear and Radiation Physics 2,25-36 , (2007).

[16]Organization for Economic Cooperation and Development, "Exposure to radiation from the natural radioactivity in building materials". Report by a group of experts of the OECD Nuclear Energy Agency, OECD, Paris, France (1979).

[17] European Commission. Radiation Protection 112" Radiological protection principles concerning the natural radioactivity of building materials", Brussels, European Commission, (1999).

[18] International Commission on Radiological Protection, ICRP publication 65, Annals of the ICRP 23(2). Pergamon Press, Oxford, (1993). 